\title{
Major Salivary Gland Cancer Clinical Distant Metastasis TNM Finding v7
}

National Cancer Institute

\section{Source}

National Cancer Institute. Major Salivary Gland Cancer Clinical Distant Metastasis TNM

Finding V7. NCI Thesaurus. Code C89126.

A clinical finding about one or more characteristics of major salivary gland cancer,

following the rules of the TNM AJCC V7 classification system as they pertain to distant metastases. 